\title{
周囲雑音を用いた無音物体搡知における 高分解能アレイ信号处理手法の比較
}

\author{
森 和義, 横山 智樹, 長谷川 秋雄 (防衛大学校) *1 \\ kmori@nda.ac.jp \\ (2004年 10 月 18 日原稿受付)
}

\begin{abstract}
:
Much attention has been paid to the new idea of detecting objects by using ocean ambient noise affirmatively. This concept is called acoustic daylight imaging. The authors have tried to detect a silent target object using ambient noise by employing a wide-band beam former consisting of an array of receivers. In experimental results obtained in air, we have applied the delay-sum array (DSA) method and the multiple signal classification (MUSIC) method to successfully detect a silent target object in an acoustic noise field generated by a large number of transducers by using a wide-band beam former. In this paper, we applied the minimum variance (MV) method to detect silent targets as one of the promising high resolution technique of the array signal processing method. The relative power levels near the target obtained with MV and MUSIC were compared with those obtained by DSA. Then, the effectiveness of the MV and MUSIC method was evaluated according to the rate of increase and the direction in the maximum relative power levels.
\end{abstract}

分 類：海中雑音, 信号処理, 観測, 計測等

キーワード : 周囲雑音, 無音物体探知, アレー信号処理, 遅延和法, 最小分散法, MUSIC 法, 音響昼光法

\section{1. はじめに}

海中における物体探知において, 周囲雑音は計測対 象の音響特性を乱し, 探知を妨げるものと考えられてき た. ところが, 海中周囲雑音を物体探知に積極的に利 用しようとする新しい考え方が注目されている.この考 え方はBuckinghamらの研究グループが提案しており, Acoustic Daylight Imaging と呼ばれている.この手法 は海中での自然周囲雑音を音源として物体からの反射 波や散乱波を検出し, その強度を各方位ごとに白黒濃
淡や疑似カラーなどで色分けして物体映像を得る計測 手法である.これは, アクテイブ方式でもパッシブ方式で もない第3の新しいソーナー方式である1).

筆者らは,この手法が様々な方向に向けた受波ビ ームによって周囲雑音の強度の変化を計測する手法 であることから, 受波器アレイによる広帯域ビームフォ 一マを利用して無音物体探知を試みてきた。これまで に, 複数の送波器によって生成される模擬雑音場中 に無音ターゲット物体を配置し,アレイ信号処理に遅 
延和法を適用して模擬雑音の様々な方向性において 探知を行った？その結果，前方照明においては物体 方向付近で相対パワーレベル(ターゲットがある場合 と無い場合の差) が強くなり，逆に後方照明において は弱〈なることがわかった ${ }^{21}$.また，遅延和法における 受波器数を変化させ, 受波ビーム幅に対する物体探 知の影響を調査した。 その結果, 計測点から見た夕 ーゲット物体に対する角度が, 受波ビームのビーム幅 に最も近づくとき, ターゲット有無による受信パワーレ ベル差が最も大きくなる傾向にあることがわかった ${ }^{3)}$.

遅延和法は古典的ビームフォーマとも呼ばれ，ハンパ ラメトリックな方向推定法である. 近年では, パラメトリ ックな手法によるアレイ信号処理がいくつか開発され， 高分解能な方向推定が可能となっている. 筆者らは, その代表的な手法の一つであるMUSIC 法を適用し， 遅延和法に比べてターゲット有無による受信パワーレ ベル差が大幅に増加し, 高コントラストな挆知結果が得 られることを確認している. しかし, MUSIC法では信 号部分空間の次元を設定する必要があり, 到来する音 波の数を既知数として与えなければならない. 周囲雑 音の音源数を想定するのは容易でなく, 設定によって は誤探知を起こす欠点があることも確認している4).

もう一つの代表的な高分解能アレイ処理アルゴリズ ムに，最小分散法がある。最小分散法は注目する方 向以外から到来する音を最小化する適応型アレイを 用い, MUSIC 法のように既知数として到来音波の数 を与える必要もなく, 取り扱いが簡単な利点がある. 本研究では,これまで検討されてきた遅延和法・ MUSIC 法に加えて, 最小分散法を用いた無音物体 の探知を試みる.ここでは, 複数の送波器によって生 成される模擬雑音場中に無音ターゲット物体を配置 して探知を行う空中模擬実験を行い, 遅延和法, 最 小分散法およびMUSIC 法による結果を比較する.

\section{2. アレイ信号処理アルゴリズム5)-7)}

\section{1 遅延和法(Delay-Sum Array：DSA)}

直線配列アレイにおける $i$ 番目の受波器の入力信 号を $z_{i}(t), i=1,2, \cdots, M(M$ は受波器数 $)$ とすると, そ のSTFT(Short-Time Fourier Transform) は

$$
x_{i}(t, \omega)=\int_{-T}^{T} z_{i}(t-\tau) W(\tau) e^{-j \omega \tau} d \tau
$$

となる. ただし, $W(t)$ は入力信号 $z_{i}(t)$ を有限区間で 切り取る時間空関数である.ここでは次のハニング空 を用いた。

$$
W(t)=\left\{\begin{array}{cc}
0.5\{1-\cos (2 \pi t / T)\} & (|t| \leq T) \\
0 & (|t|>T)
\end{array}\right.
$$

$\theta_{\mathrm{L}}$ の方向に受波ビームを向ける場合, $i$ 番目の受波 器信号のSTFTである $x_{i}(t, \omega)$ に対する遅延時間 $D_{i}\left(\theta_{\mathrm{L}}\right)$ は

$$
D_{i}\left(\theta_{\mathrm{L}}\right)=(i-1) \tau_{\mathrm{L}}\left(\theta_{\mathrm{L}}\right), \tau_{\mathrm{L}}\left(\theta_{\mathrm{L}}\right)=\frac{d \sin \theta_{\mathrm{L}}}{c}
$$

となる．ただし， $d$ は受波器間隔， $c$ は音速である. ここで, 次のベクトルと行列を定義する.

$$
\begin{aligned}
& \boldsymbol{d}\left(\omega, \theta_{\mathrm{L}}\right)=\left[e^{-j \omega D_{1}\left(\theta_{\mathrm{L}}\right)}, e^{-j \omega D_{2}\left(\theta_{\mathrm{L}}\right)}, \cdots, e^{-j \omega D_{M}\left(\theta_{\mathrm{L}}\right)}\right]^{H} \\
& \boldsymbol{x}(t, \omega)=\left[x_{1}^{*}(t, \omega), x_{2}^{*}(t, \omega), \cdots, x_{M}^{*}(t, \omega)\right]^{H} \\
& \boldsymbol{R}(\omega)=\int \boldsymbol{x}(t, \omega) \boldsymbol{x}(t, \omega)^{H} d t
\end{aligned}
$$

$H$ は共役転置, *は複素共役を表す. $\boldsymbol{d}\left(\omega, \theta_{\mathrm{L}}\right)$ は方 向制御ベクトルと呼ばれ，アレイの指向方向を制御 する. また, $\boldsymbol{R}(\omega)$ は受音した信号べクトル $\boldsymbol{x}(t, \omega)$ の受波器間の共分散行列となる。これらより, 遅延 和法における到来信号のパワーは

$$
\begin{aligned}
P_{\mathrm{DSA}}\left(\omega, \theta_{\mathrm{L}}\right) & =\int\left|\boldsymbol{d}\left(\omega, \theta_{\mathrm{L}}\right)^{H} \boldsymbol{x}(t, \omega)\right|^{2} d t \\
& =\int \boldsymbol{d}\left(\omega, \theta_{\mathrm{L}}\right)^{H} \boldsymbol{x}(t, \omega) \boldsymbol{x}(t, \omega)^{H} \boldsymbol{d}\left(\omega, \theta_{\mathrm{L}}\right) d t \\
& =\boldsymbol{d}\left(\omega, \theta_{\mathrm{L}}\right)^{H} \boldsymbol{R}(\omega) \boldsymbol{d}\left(\omega, \theta_{\mathrm{L}}\right)
\end{aligned}
$$

となる.

\section{2 最小分散法(Minimum Variance : MV)}

最小分散法は, 注目している方向 $\theta_{\mathrm{L}}$ 以外から到来す る音の影響を最小にする推定方法である. そのために は, 目的音 (方向 $\theta_{\mathrm{L}}$ から到来する音)の大きさを変化さ 
せずに雑音(方向 $\theta_{\mathrm{L}}$ 以外から到来する音)を最小化す る適応型アレイが利用される.この条件を満たす適応 型アレイのフイル夕において, 角周波数 $\omega$ および方向 $\theta_{\mathrm{L}}$ に対するゲインを $\boldsymbol{w}\left(\omega, \theta_{\mathrm{L}}\right)^{H}=\left[w_{1}\left(\omega, \theta_{\mathrm{L}}\right), w_{2}\left(\omega, \theta_{\mathrm{L}}\right)\right.$, $\left.\cdots, w_{M}\left(\omega, \theta_{\mathrm{L}}\right)\right]$ とすると, $\boldsymbol{w}\left(\omega, \theta_{\mathrm{L}}\right)^{H} \boldsymbol{d}\left(\omega, \theta_{\mathrm{L}}\right)=1$ となる ように $\boldsymbol{w}\left(\omega, \theta_{\mathrm{L}}\right)^{H} \boldsymbol{R}(\omega) \boldsymbol{w}\left(\omega, \theta_{\mathrm{L}}\right)$ を最小化させるゲイン $\boldsymbol{w}\left(\omega, \theta_{\mathrm{L}}\right)$ の解は

$$
\boldsymbol{w}\left(\omega, \theta_{\mathrm{L}}\right)^{H}=\frac{\boldsymbol{R}(\omega)^{-1} \boldsymbol{d}\left(\omega, \theta_{\mathrm{L}}\right)}{\boldsymbol{d}\left(\omega, \theta_{\mathrm{L}}\right)^{H} \boldsymbol{R}(\omega)^{-1} \boldsymbol{d}\left(\omega, \theta_{\mathrm{L}}\right)}
$$

となる.このゲインを用いるとアレイ出力は,

$$
y\left(t, \omega, \theta_{\mathrm{L}}\right)=\boldsymbol{w}\left(\omega, \theta_{\mathrm{L}}\right)^{H} \boldsymbol{x}(t, \omega)
$$

となり,そのパワーは,

$$
\begin{aligned}
& P_{\mathrm{MV}}\left(\omega, \theta_{\mathrm{L}}\right) \\
& =\int\left|\boldsymbol{w}\left(\omega, \theta_{\mathrm{L}}\right)^{H} \boldsymbol{x}(t, \omega)\right|^{2} d t \\
& =\boldsymbol{w}\left(\omega, \theta_{\mathrm{L}}\right)^{H}\left\{\int \boldsymbol{x}(t, \omega) \boldsymbol{x}(t, \omega)^{H} d t\right\} \boldsymbol{w}\left(\omega, \theta_{\mathrm{L}}\right) \\
& =\boldsymbol{w}\left(\omega, \theta_{\mathrm{L}}\right)^{H} \boldsymbol{R}(\omega) \boldsymbol{w}\left(\omega, \theta_{\mathrm{L}}\right) \\
& =\frac{1}{\boldsymbol{d}\left(\omega, \theta_{\mathrm{L}}\right)^{H} \boldsymbol{R}(\omega)^{-1} \boldsymbol{d}\left(\omega, \theta_{\mathrm{L}}\right)}
\end{aligned}
$$

となる.

\subsection{MUSIC法}

MUSIC(Multiple Signal Classification) 法は, 受 波器アレイの入力信号の共分散行列を固有值分解す ることにより到来信号の方向を推定する方法である. MUSIC 法による到来信号のパワーは次のように求め ることができる.

$$
P_{\mathrm{MUSIC}}\left(\omega, \theta_{\mathrm{L}}\right)=\frac{1}{\boldsymbol{d}\left(\omega, \theta_{\mathrm{L}}\right)^{H} \boldsymbol{R}_{n}(\omega) \boldsymbol{d}\left(\omega, \theta_{\mathrm{L}}\right)}
$$

Eq. (10)と Eq.(11)を比べると, $P_{\mathrm{MV}}\left(\omega, \theta_{\mathrm{L}}\right)$ における $\boldsymbol{R}(\omega)^{-1}$ の代わりに, $P_{\mathrm{MUSIC}}\left(\omega, \theta_{\mathrm{L}}\right)$ では $\boldsymbol{R}_{n}(\omega)$ となっ ている. この $\boldsymbol{R}_{n}(\omega)$ は, $\boldsymbol{R}(\omega)$ の小さい $L$ 個の固有值 に対応する固有べクトルを $v_{1}, v_{2}, \cdots, v_{L}$ とするとき，

$$
\boldsymbol{R}_{n}(\omega)=\sum_{i=1}^{L} \boldsymbol{v}_{i} \boldsymbol{v}_{i}^{H}
$$

と定義される.ただし, $N$ は信号部分空間の次元で あり, 到来音波の数を与える.よって, 固有值の個数 は $L=M-N$ となり, MUSIC 法では到来音波の数が 既知である必要がある.

Fig. 1 に3方に音源がある場合について遅延和 法, 最小分散法およびMUSIC 法によって到来音波の パワーレベルを推定した例を示す.ここでは, 受波器 数 $M=48$, 受波器間隔 $d=0.02 \mathrm{~m}$ とL, 周波数 2000 $\mathrm{Hz}$ で音源 1 は方向 $-60 \mathrm{deg}$ で $-10 \mathrm{~dB}$, 音源 2 は方向 $10 \mathrm{deg}$ で $0 \mathrm{~dB}$, 音源 3 は方向 $20 \mathrm{deg}$ で $-5 \mathrm{~dB}$ のパワ ーレベルを持つこととした. Fig. 1（a)は3つの手法を

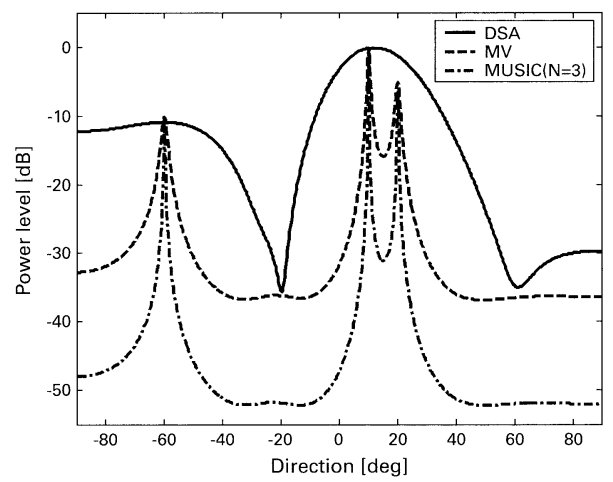

(a) DSA, MV and MUSIC

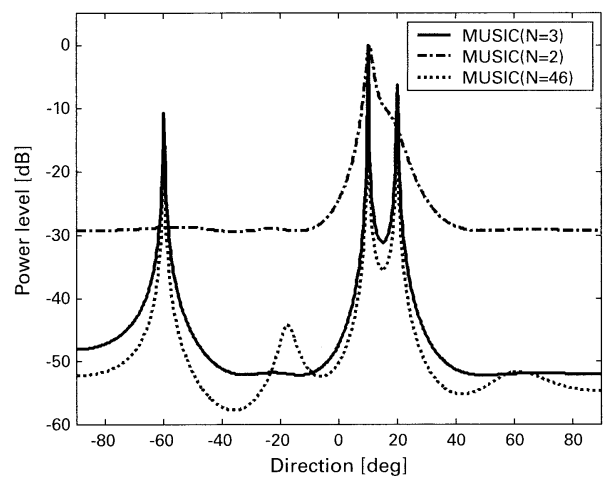

(b) MUSIC at various dimensions $N$ of signal subspace

Fig. 1 Examples of the power of arrival signals estimated using DSA, MV and MUSIC method. Here, the number of receivers is $M=48$, the separation of receivers is $d=0.02 \mathrm{~m}$, and the frequency is $2000 \mathrm{~Hz}$. There are three sound sources. First, $-60 \mathrm{deg},-10 \mathrm{~dB}$; second, $10 \mathrm{deg}, 0 \mathrm{~dB}$; and third, $20 \mathrm{deg},-5 \mathrm{~dB}$. 
比較したものであるが, 遅延和法では音源 2 と音源 3 の区別が付かないのに対して, 最小分散法とMUSIC 法では音源 2 と音源 3 で鋭いピークを形成し, 両音源 の区別を可能とする高分解能を有していることがわか る. しかし, 音源方向とそれ以外の方向のパワーレベ ルの差は, 最小分散法に比べて MUSIC 法の方が大 きくなっている. また, Fig. 1(b)はMUSIC法において 信号部分空間の次元 $N$ を様々に変化させた例であ る. $N=3$ では到来音波の数と一致しているので, 音 源方向で3つの鋭いピークを形成しているが, $N=2$ ではパワーレベルの大きい音源 2 と音源 3 だけで選択 的にピークを形成している. また, $N=46$ では-20 deg や $60 \mathrm{deg}$ 付近に音源以外の不必要なピークを形成し ていることがわかる.このように, 遅延和法は他手法 に比べて分解能が悪く, MUSIC法では信号部分空 間の次元 $N$ を適切に選ばなければならない不便さが ある. 最小分散法ではMUSIC 法と同等の分解能を 有し, MUSIC法のような設定の不便さはない.

\section{3. 実験システム}

実験システムをFig. 2 に示す. 間隔 $d=0.02 \mathrm{~m}$ で 48 個の受波器を直線配列し, その中心から $3.3 \mathrm{~m}$ 離れた ところに球形のターゲット物体を配置した. 球形ターゲ ットとして, 直径 $0.60 \mathrm{~m}$ をターゲット $\mathrm{A}$, 直径 $0.45 \mathrm{~m}$ を ターゲット Bとする. 海中周囲雑音を空中で模擬する ために, 雑音源は球形ターゲットの中心から半径 $5.5 \mathrm{~m}$ の円周上に配置された。ここで, 模擬雑音源には 8 個 の送波器が用いられ，それぞれ4個ずつの Group1 と Group2に分けられた.これらの送波器は36個の辺に 分割された円周上の各辺に配置し, Group1はNo. 1 〜 18, Group2はNo. 19～36を移動させた. このよう に模擬雑音源の位置を変えながら, 受波器信号をそ れぞれ記録した. 模擬雑音のピリオドグラム（最大值で 正規化)の例を Fig. 3に示す.これより, 1000〜7000 $\mathrm{Hz}$ でほぼ一様に分布していることがわかる.

また, 各アレイ処理においては, 計測された 48 個の 受波器信号の一部分を取り出し, 受波器数 $M$ をパラ メータとして, $M=18,24,30,36,42,48$ につて比較 することとした。 また, MUSIC法においては信号部分
空間の次元を $N=10,20,30$ として比較することとし た. 計測された信号はサンプリング周波数 $15 \mathrm{kHz}$, 量 子化ビット数 12 bitでA/D変換されて計算機に取り込 まれ，各々のアレイ信号処理が行われた. ただし，どの アレイ信号処理においても, STFTにおける空関数の 大きさは 64 点で, さらに 64 点のゼ口詰めを行い 128 点 でFFTを順次行った. 空関数の移動幅は 16 点とし, 空の移動回数は 100 回とした.これは, 1 回の測定で 1680 点, すなわち 0.112 秒間測定された信号を解析 したことになる. また, ビームの指向角度は土90 deg の 範囲を 180 分割した.ここでは, 測定を 10 回行ってア レイ処理した後に,これらを平均した到来音パワーを

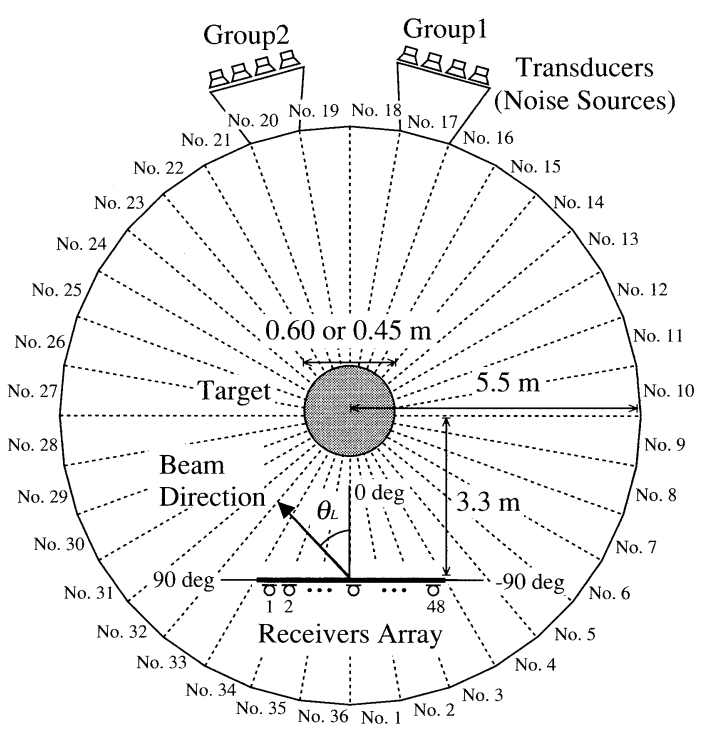

Fig. 2 Experimental arrangement.

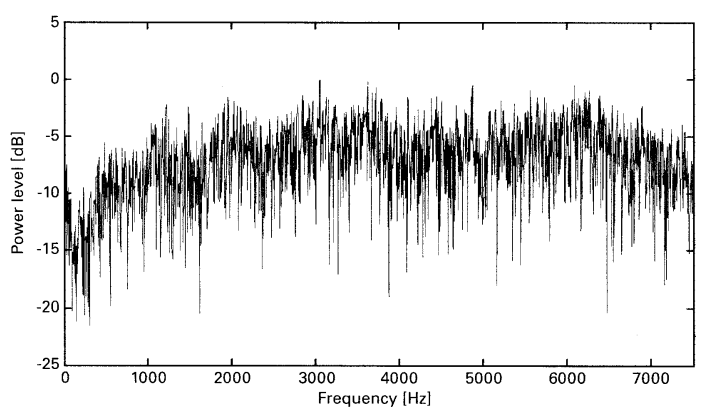

Fig. 3 Example of normalized periodogram of a noise source. 
求めている.さらに, 周囲雑音の方向性は, ターゲット 物体から見て前方に模擬雑音源が存在すると想定し, No. 4〜 10 上o. 27〜33 で模擬雑音を発生させ, 各 受波器信号を時間軸で合成することで実現した。

\section{4. 実験結果}

本研究ではターゲット物体が存在する場合と存在し ない場合のパワーのレベル差を計算し, 相対パワーレ ベルを評価の対象とした。ターゲット物体が存在する 場合のパワーを $P_{\text {target }}\left(\omega, \theta_{\mathrm{L}}\right)$, 存在しない場合のパワ 一を $P_{\text {non }}\left(\omega, \theta_{\mathrm{L}}\right)$ とすると, 相対パワーレベル $10 \log _{10}$ $P_{\mathrm{d}}\left(\omega, \theta_{\mathrm{L}}\right)$ は次のように計算される.

$$
\begin{aligned}
& 10 \log _{10} P_{\mathrm{d}}\left(\omega, \theta_{\mathrm{L}}\right) \\
& =10 \log _{10} P_{\text {target }}\left(\omega, \theta_{\mathrm{L}}\right)-10 \log _{10} P_{\text {non }}\left(\omega, \theta_{\mathrm{L}}\right) \\
& =10 \log _{10} \frac{P_{\text {target }}\left(\omega, \theta_{\mathrm{L}}\right)}{P_{\text {non }}\left(\omega, \theta_{\mathrm{L}}\right)}
\end{aligned}
$$

以下に示す図においては, 横軸がビームの指向方向 $\theta_{\mathrm{L}}$ $\operatorname{deg}$, 縦軸が周波数 $f=\omega / 2 \pi \mathrm{Hz}$, そして, 疑似カラーが 相対パワーレベル $10 \log _{10} P_{\mathrm{d}}\left(\omega, \theta_{\mathrm{L}}\right) \mathrm{dB}$ を示している.

Fig. 4 にターゲットAに扔ける相対パワーレベルの 実験結果の例を示す. (a) は $M=42$ における遅延和 法の結果を示して抢り, 方向 $2.0 \mathrm{deg}$, 周波数 3750 $\mathrm{Hz}$ で $1.74 \mathrm{~dB}$ の最大相対パワーレベルが得られてい る. (b) は同じく $M=42$ に打ける最小分散法の結果を 示しており, 方向 $0.0 \mathrm{deg}$, 周波数 $6445 \mathrm{~Hz}$ で $2.40 \mathrm{~dB}$ の最大相対パワーレベルが得られている. 遅延和法 に比べて, 最小分散法は $37.9 \%$ \%増加率である. (c) は, $M=42, N=20$ におけるMUSIC 法の結果を示し ており, 方向 $2.0 \mathrm{deg}$, 周波数 $3984 \mathrm{~Hz}$ で $3.58 \mathrm{~dB}$ の 最大相対パワーレベルが得られている.この条件の MUSIC 法は達延和法に比べて $105.7 \%$ の増加率で ある. (d)は, $M=30, N=10$ におけるMUSIC法の結 果を示して抢り, 周波数 $2813 \mathrm{~Hz} て ゙ 3.25 \mathrm{~dB}$ の最大相

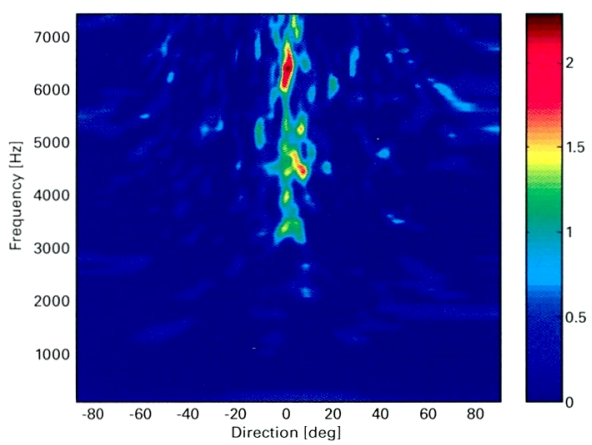

(b) MV Method $(M=42)$

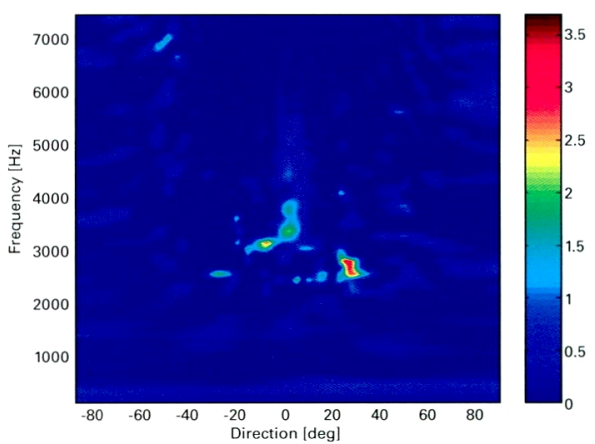

(d) MUSIC Method $(M=30, N=10)$

(c) MUSIC Method $(M=42, N=20)$

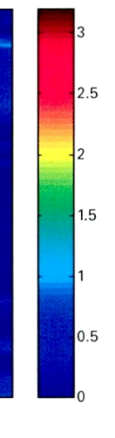

Fig. 4 Examples of relative power level at target A. 
対パワーレベルが得られているものの, その方向は $26.0 \mathrm{deg}$ となりターゲット方向と大きく異なっていること から誤探知といえる.

Table 1にターゲットAにおける相対パワーの最大レ ベル (a), 最大相対パワーレベルの増加率 (b), 最大相 対パワーレベルにおける方向 (c) および周波数 (d)を示 している. 増加率は, 遅延和法の最大相対パワーレベ ル $L_{\mathrm{DSA}}^{\max }$ を基準として計算した。最小分散法および MUSIC 法の最大相対パワーレベルをそれぞれ $L_{\mathrm{MV}}^{\max }$ ， $L_{\mathrm{MUSIC}}^{\max }$ とすると, 増加率はそれぞれ $\left(L_{\mathrm{MV}}^{\max }-L_{\mathrm{DSA}}^{\max }\right) / L_{\mathrm{DSA}}^{\max }$,
$\left(L_{\mathrm{MUSIC}}^{\max }-L_{\mathrm{DSA}}^{\max }\right) / L_{\mathrm{DSA}}^{\max }$ となる. ここで, 探知方向 $($ 最大 相対パワーレベルが得られる方向) が実際のターゲッ 卜方向より土5 deg 以上の場合を誤探知と定義した。 表の網掛け部分は誤探知の場合を示している. Table 1(c)より，遅延和法および最小分散法ではいず れの条件でも $3.0 \mathrm{deg}$ 以下となっており, 誤探知はな い.それに比べて, MUSIC法では14例中7つの条 件で誤探知を起こしており, 特に $N=10$ で誤探知が 集中している. ただし, Table 1(b)の最大相対パワー レベルの増加率においては, 最小分散法では最高で

Table 1 Comparison of maximum relative power level obtained by DSA, MV and MUSIC method in case of target A.

(a) Maximum relative power level

\begin{tabular}{|c|c|c|c|c|c|c|c|}
\hline \multirow{2}{*}{\multicolumn{2}{|c|}{$\begin{array}{c}\text { Array Processing } \\
\text { Method }\end{array}$}} & \multicolumn{6}{|c|}{ Maximum relative power level [dB] } \\
\hline & & $M=18$ & $M=24$ & $M=30$ & $M=36$ & $M=42$ & $M=48$ \\
\hline \multicolumn{2}{|c|}{ DSA } & 1.97 & 1.94 & 1.93 & 1.87 & 1.74 & 2.12 \\
\hline \multicolumn{2}{|c|}{ MV } & 2.22 & 2.14 & 2.45 & 2.08 & 2.40 & 2.26 \\
\hline \multirow{3}{*}{ MUSIC } & $N=10$ & 5.81 & 5.53 & 3.25 & 4.02 & 6.94 & 3.65 \\
\hline & $N=20$ & & 6.52 & 3.26 & 3.94 & 3.58 & 4.24 \\
\hline & $N=30$ & & & & 4.35 & 2.65 & 2.91 \\
\hline
\end{tabular}

(b) Rate of increase of maximum relative power level standardized by DSA results

\begin{tabular}{|c|c|r|r|r|r|r|r|}
\hline \multirow{2}{*}{$\begin{array}{c}\text { Array Processing } \\
\text { Method }\end{array}$} & \multicolumn{7}{|c|}{ Rate of increase [\%] } \\
\cline { 2 - 8 } & $M=18$ & $M=24$ & $M=30$ & $M=36$ & $M=42$ & $M=48$ \\
\hline \multicolumn{2}{|c|}{ MV } & 12.7 & 10.3 & 26.9 & 11.2 & 37.9 & 6.6 \\
\hline \multirow{3}{*}{ MUSIC } & $N=10$ & 194.9 & 185.1 & 68.4 & 115.0 & 298.9 & 72.2 \\
\cline { 2 - 8 } & $N=20$ & & 236.1 & 68.9 & 110.7 & 105.7 & 100.0 \\
\cline { 2 - 8 } & $N=30$ & & & & 132.6 & 52.3 & 37.3 \\
\hline
\end{tabular}

(c) Direction at maximum relative power level

\begin{tabular}{|c|c|c|c|c|c|c|c|}
\hline \multirow{2}{*}{\multicolumn{2}{|c|}{$\begin{array}{c}\text { Array Processing } \\
\text { Method }\end{array}$}} & \multicolumn{6}{|c|}{ Direction [deg] } \\
\hline & & $M=18$ & $M=24$ & $M=30$ & $M=36$ & $M=42$ & $M=48$ \\
\hline \multicolumn{2}{|c|}{ DSA } & 2.0 & 1.0 & 1.0 & 1.0 & 2.0 & 2.0 \\
\hline \multicolumn{2}{|c|}{ MV } & 2.0 & 2.0 & 0.0 & 3.0 & 0.0 & 0.0 \\
\hline \multirow{3}{*}{ MUSIC } & $N=10$ & 5.0 & 3.0 & 26.0 & 11.0 & 5.0 & 4.0 \\
\hline & $N=20$ & & 69.0 & 0.0 & 0.0 & 2.0 & 3.0 \\
\hline & $N=30$ & & & & 1.0 & 7.0 & 7.0 \\
\hline
\end{tabular}

(d) Frequency at maximum relative power level

\begin{tabular}{|c|c|c|c|c|c|c|c|}
\hline \multirow{2}{*}{\multicolumn{2}{|c|}{$\begin{array}{c}\text { Array Processing } \\
\text { Method }\end{array}$}} & \multicolumn{6}{|c|}{ Frequency $[\mathrm{Hz}]$} \\
\hline & & $M=18$ & $M=24$ & $M=30$ & $M=36$ & $M=42$ & $M=48$ \\
\hline \multicolumn{2}{|c|}{ DSA } & 6445 & 6445 & 6563 & 6563 & 3750 & 3750 \\
\hline \multicolumn{2}{|c|}{ MV } & 6445 & 6563 & 6445 & 7383 & 6445 & 6445 \\
\hline \multirow{3}{*}{ MUSIC } & $N=10$ & 4336 & 3281 & 2813 & 2461 & 1758 & 1523 \\
\hline & $N=20$ & & 3281 & 5039 & 4102 & 3984 & 3281 \\
\hline & $N=30$ & & & & 6797 & 4453 & 4336 \\
\hline
\end{tabular}


も37.9\%であるのに対し, MUSIC法では100\%を 超えるものが多く, 増加率は最小分散法に比べて MUSIC 法が大きい.

Fig. 5 にターゲットBに抢ける相対パワーレベルの 実験結果の例を示す. (a) は $M=48$ に打ける遅延和 法の結果を示して抢り, 方向 $1.0 \mathrm{deg}$, 周波数 6445 $\mathrm{Hz}$ で $1.22 \mathrm{~dB}$ の最大相対パワーレベルが得られてい る. (b)は同じく $M=48$ に执ける最小分散法の結果を 示しており, 方向 $1.0 \mathrm{deg}$, 周波数 $6445 \mathrm{~Hz}$ で $1.91 \mathrm{~dB}$ の最大相対パワーレベルが得られている. 遅延和法 に比べて, 最小分散法は $56.6 \%$ 増加率である. (c) は, $M=42, N=20$ に打けるMUSIC 法の結果を示し て打り, 方向 $0.0 \mathrm{deg}$, 周波数 $3633 \mathrm{~Hz}$ で $3.30 \mathrm{~dB}$ の 最大相対パワーレベルが得られている.この条件の MUSIC 法は遅延和法に比べて $189.5 \%$ \%增加率で ある. (d)は $M=18, N=10$ に扔けるMUSIC法の結 果を示しており，周波数 $4102 \mathrm{~Hz}$ で $5.50 \mathrm{~dB}$ の最大相

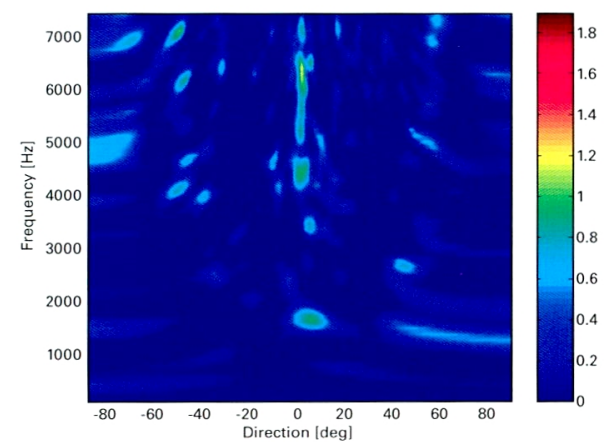

(a) DSA Method $(M=48)$

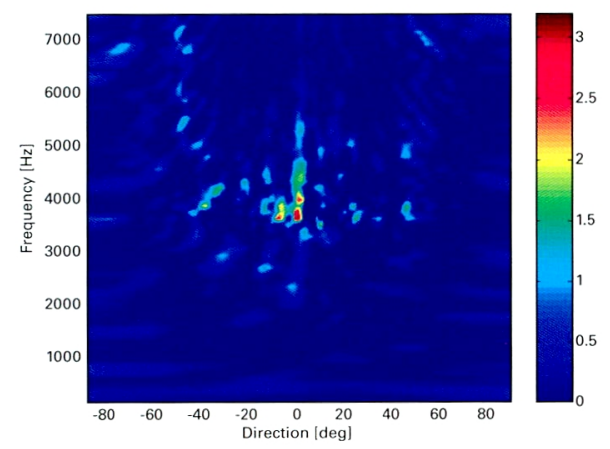

(c) MUSIC Method $(M=42, N=20)$
対パワーレベルが得られているものの，その方向は $18.0 \mathrm{deg}$ となりターゲット方向と大きく異なっているこ とから誤探知といえる.

Table 2にターゲットBに抢ける相対パワーの最大 レベル (a), 最大相対パワーレベルの增加率 (b), 最 大相対パワーレベルに打ける方向(c)抢よび周波数 (d) を示している. Table 2(c)より, 遅延和法拉よび最小 分散法ではいずれの条件でも $3.0 \mathrm{deg}$ 以下となってお り，ターゲットが小さくなっても誤探知はない，それに 比べて, MUSIC法では全条件の半数で誤探知を起 こしており， $N=10$ で誤探知が集中しているのも Table 1 (c)の結果と同様である. また, Table 2(b)の最大相 対パワーレベルの増加率に扔いて, MUSIC 法は最小 分散法に比べて大きいことも Table 1 (b) と同様であ る、ただし，ターゲットが小さくなっていることから， Table 2(a)の最大相対パワーレベルはTable 1 (a)に 比べて小さいことが分かる.

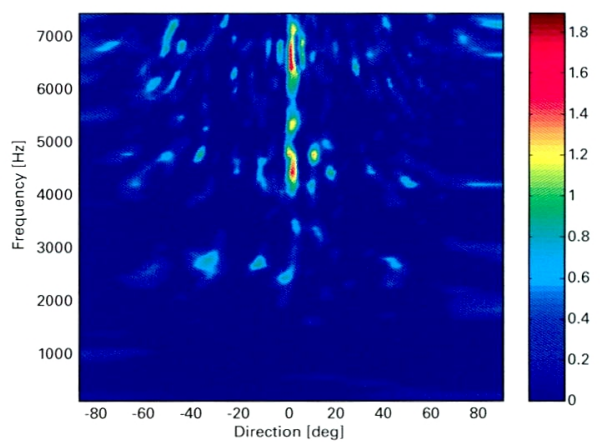

(b) MV Method $(M=48)$

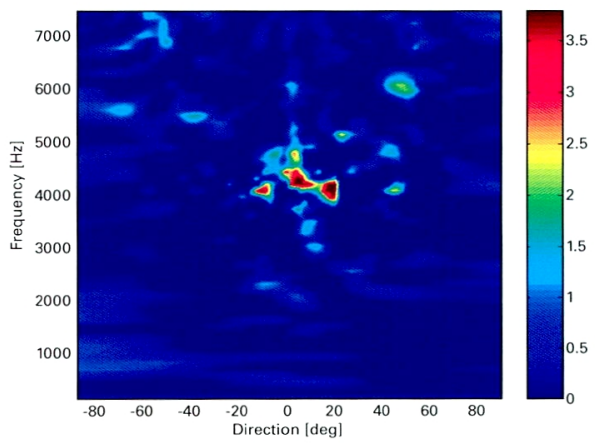

(d) MUSIC Method $(M=18, N=10)$

Fig. 5 Examples of relative power level at target B. 
Table 2 Comparison of maximum relative power level obtained by DSA, MV and MUSIC method in case of target B.

(a) Maximum relative power level

\begin{tabular}{|c|c|c|c|c|c|c|c|}
\hline \multirow{2}{*}{\multicolumn{2}{|c|}{$\begin{array}{c}\text { Array Processing } \\
\text { Method }\end{array}$}} & \multicolumn{6}{|c|}{ Maximum relative power level $[\mathrm{dB}]$} \\
\hline & & $M=18$ & $M=24$ & $M=30$ & $M=36$ & $M=42$ & $M=48$ \\
\hline \multicolumn{2}{|c|}{ DSA } & 1.04 & 1.18 & 1.14 & 1.14 & 1.14 & 1.22 \\
\hline \multicolumn{2}{|c|}{ MV } & 1.48 & 1.76 & 1.54 & 1.61 & 1.73 & 1.91 \\
\hline \multirow{3}{*}{ MUSIC } & $N=10$ & 5.50 & 4.41 & 4.55 & 3.62 & 3.29 & 3.82 \\
\hline & $N=20$ & & 6.14 & 2.33 & 3.89 & 3.30 & 2.68 \\
\hline & $N=30$ & & & & 3.43 & 2.42 & 2.25 \\
\hline
\end{tabular}

(b) Rate of increase of maximum relative power level standardized by DSA results

\begin{tabular}{|c|c|r|r|r|r|r|r|}
\hline \multirow{2}{*}{$\begin{array}{c}\text { Array Processing } \\
\text { Method }\end{array}$} & \multicolumn{7}{|c|}{ Rate of increase [\%] } \\
\cline { 2 - 8 } & $M=18$ & $M=24$ & $M=30$ & $M=36$ & $M=42$ & $M=48$ \\
\hline \multicolumn{2}{|c|}{ MV } & 42.3 & 49.2 & 35.1 & 41.2 & 51.8 & 56.6 \\
\hline \multirow{3}{*}{ MUSIC } & $N=10$ & 428.8 & 273.7 & 299.1 & 217.5 & 188.6 & 213.1 \\
\cline { 2 - 8 } & $N=20$ & & 420.3 & 104.4 & 241.2 & 189.5 & 119.7 \\
\cline { 2 - 8 } & $N=30$ & & & & 200.9 & 112.3 & 84.4 \\
\hline
\end{tabular}

(c) Direction at maximum relative power level

\begin{tabular}{|c|c|c|c|c|c|c|c|}
\hline \multirow{2}{*}{\multicolumn{2}{|c|}{$\begin{array}{c}\text { Array Processing } \\
\text { Method }\end{array}$}} & \multicolumn{6}{|c|}{ Direction [deg] } \\
\hline & & $M=18$ & $M=24$ & $M=30$ & $M=36$ & $M=42$ & $M=48$ \\
\hline \multicolumn{2}{|c|}{ DSA } & 1.0 & 1.0 & 3.0 & 0.0 & 1.0 & 1.0 \\
\hline \multicolumn{2}{|c|}{ MV } & 2.0 & 1.0 & 2.0 & 0.0 & 1.0 & 1.0 \\
\hline \multirow{3}{*}{ MUSIC } & $N=10$ & 18.0 & -27.0 & 1.0 & -4.0 & 8.0 & 7.0 \\
\hline & $N=20$ & & 2.0 & -25.0 & 9.0 & 0.0 & 4.0 \\
\hline & $N=30$ & & & & 0.0 & 1.0 & -11.0 \\
\hline
\end{tabular}

(d) Frequency at maximum relative power level

\begin{tabular}{|c|c|r|r|r|r|r|r|}
\hline \multirow{2}{*}{$\begin{array}{c}\text { Array Processing } \\
\text { Method }\end{array}$} & \multicolumn{7}{|c|}{ Frequency [Hz] } \\
\cline { 2 - 8 } & $M=18$ & $M=24$ & $M=30$ & $M=36$ & $M=42$ & $M=48$ \\
\hline \multicolumn{2}{|c|}{ DSA } & 6563 & 6563 & 6563 & 4570 & 4453 & 6445 \\
\hline \multicolumn{2}{|c|}{ MV } & 6563 & 6563 & 6563 & 6797 & 6445 & 6445 \\
\hline \multirow{3}{*}{ MUSIC } & $N=10$ & 4102 & 3164 & 2461 & 2109 & 1992 & 1523 \\
\cline { 2 - 8 } & $N=20$ & & 6563 & 4922 & 4102 & 3633 & 3281 \\
\cline { 2 - 8 } & $N=30$ & & & & 5156 & 4453 & 4570 \\
\hline
\end{tabular}

\section{5. おわりに}

本研究では, 複数の送波器によって生成される模 擬雑音場中に無音ターゲット物体を配置して探知を 行う空中模擬害験を行い, 遅延和法, 最小分散法お よびMUSIC 法による結果を比較した。これより, 次の ような結果が得られた。

・最小分散法は遅延和法に比べて, ターゲット方 向での相対パワーレベルが増加し, より高コント ラストな探知結果を得られることが分かった。
・最小分散法および遅延和法は, 今回の実験で試 したすべての条件に扔いて誤探知がなかった.

- MUSIC 法は信号部分空間の次元 $N$ の設定に より誤探知を起こすことが多く, 今回の実験で試 した条件の半数で䛈探知がみられた。

・MUSIC 法は, 誤探知がない場合には, 遅延和法 および最小分散法に比べてターゲット方向での相 対パワーレベルが極端に増加することがわかった。

以上のように, 最小分散法はMUSIC 法ほどの高コン 
トラスト化は得られないが, MUSIC法における $N$ の設 定による不安定さが無く, 安定した結果が得られている. その点で最小分散法は, 周囲雑音を用いた無音物体 探知において導入が容易な高分解能アレイ信号処理 手法であるといえる. MUSIC法においては, 信号部分 空間の次元 $N$ の決定方法を開発することが大きな課 題といえる. 今後は, 後方照明や全周囲照明などの模 擬雑音の様々な方向性における検討が必要である.

\section{参考文献}

1) M. J. Buckingham, B. V. Verkhout and S. A. L. Glegg, "Imaging the Ocean with Ambient Noise," Nature, 356, 327-329 (1992).

2) K. Mori, M. Matsuda and S. Ozaki, "Passive Detection of Silent Target Object by Ambient Noise: Some Experimental Results using Wideband Beamformer by an Array of Receivers," J. Marine Acoust. Soc. Jpn., 29(4), 43-51 (2002).
3) K. Mori, T. Yokoyama, A. Hasegawa and M. Matsuda, "Effect of Received Beam Width on Passive Detection of Silent Target Using Ambient Noise," Jpn. J. Appl. Phys., 42(5B), 3200-3205 (2003).

4) K. Mori, T. Yokoyama, A. Hasegawa and M. Matsuda, "Applying the Multiple Signal Classification Method to Silent Target Detection Using Ambient Noise," Jpn. J. Appl. Phys., 43(5B), 3146-3153 (2004).

5）大賀寿朗, 山崎芳男, 金田 豊, 音響システム とデイジタル処理, (電子情報通信学会, 東京, 1995) p. 199-209.

6) 田中雅史, 金田 豊, 小島順治, “音源方向推 定法の室内残響下での性能評価," 日本音響学 会誌, 50(7), 540-548 (1994).

7）沖田芳雄, "信号処理の将来動向," 海洋音響学 会誌, 27(4), 202-204 (2000). 